\title{
Estimation of Heterosis, Gene Action and Combining Ability over Environments for Improvement of Fruit Yield and its Related Traits in Okra [Abelmoschus esculentus (L.) Moench]
}

\author{
R. D. Vekariya ${ }^{1 *}$, A. I. Patel ${ }^{2}$, K. G. Modha ${ }^{1}$, C. V. Kapadiya ${ }^{2}$, \\ S. C. Mali ${ }^{3}$ and A. A. Patel ${ }^{1}$ \\ ${ }^{1}$ Genetics and Plant Breeding, NMCA, ${ }^{2}$ ASPEE College of Horticulture and Forestry, ${ }^{3}$ Main \\ Sugarcane Research Station, NAU, Navsari-396 450, India \\ *Corresponding author
}

\section{Ke y w o r ds \\ Heterosis, Gene interaction, Combining ability, Line x Tester analysis, okra [Abelmoschus esculentus (L.) Moench]}

Article Info

Accepted: 10 August 2020 Available Online: 10 September 2020

\section{A B S T R A C T}

The present investigation was carried out to study heterosis, combining ability and gene interactions over environments of parents and their crosses in kharif 2018. The experimental material, consisting of eleven lines, five testers and their resultant 55 hybrids along with a commercial hybrid check 'OH-102' of okra were sown in three different locations of south Gujarat viz., College farm, NMCA, NAU, Navsari (E1), Cotton Research Sub Station, NAU, Achhalia (E2) and Regional Rice Research Station, NAU, Vyara (E3). Observations on sixteen traits were recorded for each and every location. The analysis of variances for individual as well as pooled over environments revealed considerable genetic variation present among the parents and their hybrids for all the traits under study. The hybrids viz., JOL-14-10 X Arka Abhay, JOL-14-10 X GJO-3 and JOL13-05 X GJO-3 exhibited higher but non-significant standard heterosis for fruit yield at all locations. Non-significant but desirable standard heterosis for fruit yield and its component traits suggested that there is no scope of exploiting heterosis commercially, but the possibility of isolating desirable segregants among these hybrid combinations. The higher magnitude of non-additive variance was higher for fruit yield and its contributing traits revealed the preponderance of non-additive gene action for the majority of the traits, hence these traits can be improved through recurrent selection for specific combining ability or through heterosis breeding program. The estimates of gca effects indicated that parents viz., JOL-14-10, GJO-3 and JOL-13-05 were good general combiners for fruit yield and its contributing traits. None of the hybrids exhibited higher per se performance, sca effects and standard heterosis for fruit yield for all locations.

\section{Introduction}

Okra (Abelmoschus esculentus [L.] Moench) is an annual vegetable crop grown in tropical and subtropical regions of the world. It is quite popular in India because of easy cultivation, dependable yield and adaptability to varying moisture conditions. It is essentially a native of Africa but a few wild types have also been found in India. It 
belongs to genus Abelmoschus of family Malvaceae. Varying number of chromosomes ranging from $2 n=56$ to $2 n=199$ were reported by several workers in okra (Anon., 2011). It is a polyploid, with most observed chromosome number of $2 \mathrm{n}=130$ and an often cross pollinated crop, a highly variable cross pollination rate from 0 to $69 \%$ has been recorded for A. esculentus (Charrier, 1984). Considering the potentiality of this crop there is a prime need for its improvement and to develop varieties and hybrids suitable for specific agro-climatic zones. An important challenge would be to develop a variety/hybrid which responds well to resources and should be resistant to yellow mosaic virus and enation leaf curl virus also. To exploit the heterosis for potential yield components, knowledge of genetic architecture of fruit yield and its attributes is important in crop improvement.

Without a broad genetic base of heterogeneous plant material, it is impossible for plant breeders to produce cultivars that meet the changing needs regarding adaptation to growing conditions, resistance to biotic and abiotic stresses, product yield or specific quality requirements (Friedt et al., 2007). Therefore, availability of genetic diversity is the pre-requisite for the success of any crop improvement program. Genetic diversity either exists naturally in the gene pool or it is created artificially by using different methods (Poehlman and Sleper, 1995). The knowledge of heterosis, combining ability and nature of gene action for various traits could be helpful in predicting the effectiveness of selection and very useful for understanding the course of evolution in the varieties. Exploitation of heterosis in okra has been recognized as a practical tool in providing the breeders a means of improving yield and other important traits. For developing promising varieties through hybridization, the choice of parents is a matter of great concern to the plant breeder.
A high yielding genotype may or may not transmit its superiority to its progenies. Therefore, the success of a breeding programme is determined by useful gene combinations in the form of high combining inbred. The occurrence of heterosis is common in plant species, but its level of expression is highly variable. Hybrid vigor in okra has been first reported by Vijayaraghavan and Warier (1946). For a sound hybridization program parents should be selected not only on the basis of their diversity but also on the basis of their combining ability effects. Knowledge on combining ability is useful for selection of desirable parents for exploitation of hybridity and transgressive expressions. Combining ability studies also give idea about the nature and magnitude of gene action and gene interactions involved in the inheritance of okra fruit yield and its related characters. The knowledge of nature of gene action governing the expression of various traits could be helpful in predicting the effectiveness of selection. The efficient partitioning of genetic variance into its components viz; additive, dominance and epistatis will help in formulating an effective and sound breeding programme. Several approaches are available for assessing the parents and cross combinations with respect to combining ability. Among these, Line x Tester analysis technique proposed by Kempthorne (1957) is popular and systematic approach for identification of superior parents and crosses, which is the basic requirement of success in any hybridization breeding programme.

\section{Materials and Methods}

The experimental material consists of 11 advanced breeding lines viz., AOL-12-52, AOL-12-59, AOL-13-73, AOL-12-144, AOL12-133, AOL-14-32, JOL-69-05, JOL-11-12, JOL-13-05, JOL-14-10 and JDNOL-11-12 and five testers viz., GJO-3, GAO-5, Parbhani 
Kranti, Arka Anamika and Arka Abhay. A total $55 \mathrm{~F}_{1}$ hybrids were derived by crossing 11 lines and 5 testers using Line $\times$ Tester mating design during Kharif 2017 at Regional Horticulture Research Station, Navsari Agricultural University, Navsari, Gujarat. The $55 \mathrm{~F}_{1}$ hybrids and their 16 parents were evaluated along with one commercial check $(\mathrm{OH}$ 102) in a randomized block design (RBD) with replicated thrice at different locations viz., College farm, N. M. College of Agriculture, Cotton Sub-Research Station, Achhalia and Regional Rice Research Station, Vyara, Navsari Agricultural University, Navsari (Gujrat) during kharif 2018. Each entry was sown in a single row plot of ten plants, spaced $60 \times 30 \mathrm{~cm}$. Five plants were randomly selected for each genotype from each replication and evaluated for all the qualitative as well as quantitative characters such as days to $50 \%$ flowering, first flowering node, internodal length $(\mathrm{cm})$, branches per plant, fruits per plant, plant height $(\mathrm{cm})$, days to first picking, days to last picking, fruit length $(\mathrm{cm})$, fruit diameter $(\mathrm{mm})$, stalk length $(\mathrm{cm})$, fruit weight $(\mathrm{g})$, seeds per fruit, 100seed weight $(\mathrm{g})$, fruit yield per plant $(\mathrm{g})$ and fiber content $(\%)$ were recorded from 16 parents and $55 \mathrm{~F}_{1}$ hybrids. The mean values of the data recorded were subjected to Line $X$ Tester analysis and magnitude of gene action and the combining ability analysis was carried out as per the method given by Kempthorne (1957) and Singh (1973) in individual as well as pooled over environments, also estimate the interaction of general and specific combining ability effects with environments among parents and hybrids, respectively using statistical software INDOSATE, Department of Genetic \& Plant Breeding, Navsari Agriculture University, Navsari, Gujarat, India. Magnitude of heterosis was calculated as per standard procedure and significance of heterosis was worked out using the formula suggested by Wynne et al (1970).

\section{Results and Discussion}

\section{Magnitude of economic heterosis}

The utility of hybrid breeding approach lies in the identification of most heterotic and useful cross combination in order to make commercial cultivation of hybrids beneficial. In present investigation, hybrids viz., JOL-14$10 \mathrm{X}$ Arka Abhay at Navsari, JOL-14-10 X GJO-3, JDNOL-11-12 X GAO-5 and AOL12-52 X Arka Anamika at Achhalia and JOL13-05 X GJO-3 and AOL-12-144 X GJO-3 at Vyara were most promising for fruit yield per plant are depicted in Table 1 along with their mean performance, heterotic effects and $g c a$ and sca effects. Component wise examination of the hybrids (Table 1) revealed that best hybrids showed positive but non-significant standard heterosis for fruit yield per plant and its attributed traits like branches per plant, plant height, fruits per plant (except Achhalia), fruit length, fruit diameter, fruit weight, internodal length and days to last picking (except Achhalia) in each individual location, indicated that yield contributing traits were less contributing to fruit yield per plant and due to this reason top yielding hybrids at Navsari, Achhalia and Vyara exhibited poor and low heterotic response over standard check. The Probable explanation for these non-significant and nonheterotic hybrids were, may be ascribed to the cancellation of positive and negative effect shown by the parents involved in a cross combinations and can also happen when the dominance is not unidirectional (Gardner and Eberhart, 1966; Mather and Jinks, 1982). It was observed that not all yield contributing traits equally contributed towards heterosis, because the component traits competed for the sum total of metabolic substances produced by the plant and the conditions which favored the development of one component could have adversely affected the other one. Therefore, to obtain maximum 
yield in a selection programme desired levels of each component need to be known (More, 2015 and Satish et al., 2017). In the present study, the heterotic performance was may be highly affected by the genetic background of parental genotypes also. Similar results were reported by Medagam et al., (2013), Solankey et al., (2013), Tiwari et al., (2015), Verma and Sood (2015), Satish et al., (2017) and Kerure and Pitchaimuthu (2018). The manifestation of undesirable heterosis observed in some of the hybrids for different traits may be due to the combination of the unfavorable genes of the parents (Medagam et al., 2013). All the mean based top hybrids JOL-14-10 X Arka Abhay at Navsari and JDNOL-11-12 X GAO-5 and AOL-12-52 X Arka Anamika at Achhalia, depicted significant positive sca effects for fruit yield per plant indicated involvement of nonadditive gene action in the heterotic response of these hybrids (Satish et al., 2017). Beside high sca effects, none of the hybrid exhibited significant and positive heterosis in each location for fruit yield per plant. Top high heterotic crosses for fruit yield involved good $\mathrm{x}$ poor combination at Navsari, good $\mathrm{x}$ good combination at Achhalia and Vyara (Table 1). The Probable explanation for this type of behavior stands from the fact that poor yielding parents could have different constellation of genes were showing complementary interaction when brought together in hybrid combination (Das et al., 2013).

It is clear from the above discussion that the non-significant and desirable heterosis over standard check for fruit yield and its component traits suggested that there is no scope of exploiting heterosis commercially, but possibility of isolating desirable segregants among this hybrid combination. Manifestation of heterosis for all the traits in single cross may not be possible, but the exploitation of hybrid vigor in one or more yield-attributing traits will significantly improve the crop performance over existing hybrid or variety (Hosamani et al., 2008). While formulating suitable breeding methodology for the improvement in this crop, attention must be paid for the improvement of visual appearance as well as the biochemical qualitative aspects too, besides the productivity.

\section{Combining ability studies}

\section{ANOVA for combining ability and gene action}

Analysis of variance for combining ability over the environments (Table 2 and 3) revealed that mean squares due to environment were highly significant for all the traits (except fruit diameter and fiber content), which indicated considerable differences among the environments under which the study was conducted and suggested the influence of environments on inheritance of these characters. The mean squares due to females were significant for days to $50 \%$ flowering at Navsari and in pooled analysis; branches per plant at Vyara; fruits per plant at Achhalia and in pooled analysis; plant height at Achhalia and in pooled analysis; days to first picking at Navsari and in pooled analysis and seeds per plant at Navsari and Vyara.

The mean square due to males was significant for only three traits like fruits per plant and fruit yield under individual and in pooled over the environments and fruit diameter at Achhalia and Vyara. Significant both females and males suggested its significant contribution in favour of general combining ability ( $g c a$ ) variance towards these traits and contributed towards additive genetic variance. The mean squares due to females $\mathrm{x}$ males were manifested highly significant by all the traits in individual as well as pooled over environment, it suggested its significant 
contribution in favor of specific combining ability (sca) variances and the result thus indicated that females behave differently with different males or vice-versa. This indicated that it contributed towards non-additive genetic variance.

The sensitivity of both $g c a$ and $s c a$ variances for environmental variations indicated that evaluation of genotypes in multi-location trials would be essential for estimating these variances with reliable precision. In present study, both $g c a$ and sca variances were significant for majority of the characters studied suggested that both additive and nonadditive variances were important in the expression of these traits. However, scrutiny of $\sigma^{2} g c a / \sigma^{2} s c a$ ratio in individual as well as pooled over environments, revealed preponderance of non-additive gene action for all the traits except fruit diameter at Vyara and in pooled analysis and 100 seed weight at Navsari.

The importance of non-additive genetic variances for fruit yield per plant has been reported by several workers such as Oyetunde and Ariyo (2014), Bhat et al., (2015), More et al., (2015) and Makdoomi et al., (2018). Fruit diameter at Vyara and in pooled analysis and 100 seed weight at Navsari was revealed preponderance of both additive and nonadditive gene action for expression of these traits. From the present results, it was evident that the non additive gene action had greater role in the expression of all the traits under study, hence, merely selection will result no or slow for genetic improvement. Successful breeding methods are those that accumulate the genes to form superior gene constellations interacting in a favorable manner. The importance of non additive gene action for all yield components and quality traits in the present study indicated that important of recurrent selection for specific combining ability for improving these traits in okra.

\section{Estimates of general combining ability effects}

Nature and magnitude of combining ability effects helps in identifying superior parents and their utilization in further breeding programme. The parents classified as good, average and poor combiners based on estimates of general combining ability ( $\mathrm{gca}$ ) effects in individual as well as pooled over environment basis for various traits. In the present study, significant gca effects were observed for majority of the traits studied in each individual environments. None of the parent exhibited significant and desirable gca effects for all the traits. The analysis revealed that among parents, JOL-14-10, GJO-3, JOL69-05 and Arka Anamika at Navsari; JOL-1410, GJO-3, JDNOL-11-12 and Arka Anamika at Achhalia, GJO-3, JOL-13-05, JDNOL-1112, GAO-5 and Arka Anamika at Vyara and GJO-3, JOL-14-10, JOL-13-05, JDNOL-1112, Arka Anamika, JOL-69-05 and GAO-5 in pooled analysis exhibited significant and positive $\mathrm{gca}$ effects for fruit yield per plant. The parents, GJO-3 and Arka Anamika at Navsari, Achhalia and Vyara and in pooled analysis; JOL-14-10 at Navsari, Achhalia and in pooled analysis; JDNOL-11-12 at Achhalia, Vyara, and in pooled analysis reported significant gca effects in individual as well pooled over location indicated that general combining ability of these parents were less influenced by environment. The parent JOL-14-10 exhibited higher gca effects for fruit yield per plant was also exhibited significant $g c a$ effects for fruit per plant, days to $50 \%$ flowering and days to first picking at Navsari. The same parent also exhibited highest significant $\mathrm{gca}$ effects for fruit yield per plants, fruit per plant, days to $50 \%$ flowering, days to first picking and seeds per fruits at Achhalia. The parent GJO-3 exhibited higher gca effects for fruit yield per plant was also exhibited significant gca effects for intermodal length, fruits per plant 
and plant height at Vyara and the same parent also exhibited highest significant gca effects for fruit yield per plants, fruit per plant, first flowering node and plant height in pooled over the environments.

In present investigation, estimates of $\mathrm{gca}$ effects of the parental lines showing high $\mathrm{gca}$ effects for fruit yield per plant also exhibited high to average $g c a$ effects for majority of its yield components. It was also interesting to note that involvement of parents with good gca effects had resulted into hybrids expressing useful heterosis for various traits in majority of cases. Similar results was reported by Medagam et al., (2012), Das et al., (2013), Katagi et al., (2015), More et al., (2017) and Satish et al., (2017).

The estimates of $g c a$ effects also revealed that none of the parents showed consistently significant and desirable gca effects for all the traits (Bhatt et al., 2015, More et al., 2017 and Makdoomi et al., 2018). Parents with superior combining ability can be intensively used in the hybridization programme aimed at amelioration of fruit yield. In order to synthesize dynamic population with most of the favourable genes accumulated, it will be pertinent to make use of the aforesaid parents which were good general combiners for several traits in a multiple crossing programme. Patil (2013) reported that involvement of parents with good gca effects had resulted into hybrids expressing useful heterosis for various traits in majority. But in present investigation, parents those are involved in top hybrids for yield were good general combiner did not resulted into useful heterosis.

\section{Estimates specific combining ability effects}

Top four hybrids for fruit yield per plant viz., JOL-13-05 X Parbhani Kranti, AOL-14-32 X Parbhani Kranti, JOL-11-12 X Arka Anamika and AOL-13-73 X GJO-3 at Navsari; AOL14-32 X Parbhani Kranti, AOL-12-59 X Arka Abhay, AOL-12-133 X Parbhani Kranti and JOL-11-12 X GAO-5 at Achhalia; AOL-1432 X Parbhani Kranti, JOL-13-05 X Parbhani Kranti, AOL-12-59 X Arka Abhay and AOL12-144 X Arka Abhay at Vyara and AOL-1432 X Parbhani Kranti, AOL-12-59 X Arka Abhay, AOL-12-144 X Arka Abhay and JOL11-12 X Arka Anamika in pooled analysis exhibited higher sca effects.

Considering the overall performance of the hybrids in individual and over the environments with respect to fruit yield per plant; a total of nine, eleven, four and ten hybrids displayed positive and significant sca effects at Navsari, Achhalia, Vyara and in pooled analysis, respectively.

For various yield components significant and desirable sca effects were noticed in several hybrids for number of days $50 \%$ flowering (one, sixteen, six and four), for inter nodal length (nine, two, seven and seven), for branches per plant (nine, five, four and seven), for fruits per plant (ten, fourteen, four and thirteen), for plant height (three, eight, five and four), for days to first picking (one, fifteen, five and four), for days to last picking (three, eight, two and three), for fruit length (thirteen, eight, nine and nine), for fruit diameter (five, seven, two and four), for fruit weight (one, three, one and four), for stalk length (two, two, nine and five), for seeds per fruit (zero, three, one and five), for 100 seed weight (one, five, zero and two) and for fiber content (three, six, ten and nine) at Navsari, Achhalia, Vyara and in pooled analysis, respectively. The estimates of sca effects revealed that none of the hybrids exhibited consistently significant and desirable sca effects for all the traits. Similar result was reported by Poshiya and Shukla (1986), Balakrishnan et al., (2009) and Kayande et al., (2018). 
Table.1 Promising hybrids for fruit yield per plant with standard heterosis, gca effects, sca effects and component traits showing significant desired heterosis at Navsari, Achhalia and Vyara

\begin{tabular}{|c|c|c|c|c|c|c|c|}
\hline \multirow{2}{*}{$\begin{array}{l}\text { Sr. } \\
\text { No. }\end{array}$} & \multirow[t]{2}{*}{ Hybrid } & \multirow{2}{*}{$\begin{array}{l}\text { Fruit yield } \\
\text { per plant } \\
\text { (g) }\end{array}$} & \multirow{2}{*}{$\begin{array}{l}\text { Standard } \\
\text { heterosis }(\%) \\
\text { over check OH- } \\
102(304.18)\end{array}$} & \multicolumn{2}{|c|}{ gca effects } & \multirow[t]{2}{*}{ sca effects } & \multirow{2}{*}{$\begin{array}{c}\text { Useful and significant for } \\
\text { component traits Standard } \\
\text { heterosis }(\%)\end{array}$} \\
\hline & & & & $\mathrm{P}_{1}$ & $\mathrm{P}_{2}$ & & \\
\hline \multicolumn{8}{|c|}{ NAVSARI } \\
\hline 1. & JOL-14-10 X Arka Abhay & 310.96 & $2.23(\mathrm{~A})$ & $34.462 * *(\mathrm{G})$ & $-7.251(\mathrm{P})$ & $32.514 *(\mathrm{G})$ & Stalk length \\
\hline \multicolumn{8}{|c|}{ ACHHALIA } \\
\hline 1. & JOL-14-10 X GJO-3 & 335.60 & $8.64(\mathrm{~A})$ & $37.901 * *(\mathrm{G})$ & $29.775 * *(\mathrm{G})$ & $19.372(\mathrm{~A})$ & $\begin{array}{l}\text { Seeds per fruit, fruits per plants and } \\
\text { days to last picking }\end{array}$ \\
\hline 2. & JDNOL-11-12 X GAO-5 & 320.34 & $3.70(\mathrm{~A})$ & $22.792 * *(\mathrm{G})$ & $3.061(\mathrm{~A})$ & $45.932 * *(\mathrm{G})$ & Stalk length and Fiber content \\
\hline 3 & AOL-12-52 X Arka Anamika & 310.22 & $0.42(\mathrm{~A})$ & $9.714(\mathrm{~A})$ & $9.511 *(\mathrm{G})$ & $42.439 * *(\mathrm{G})$ & Seeds per fruit and fruits per plants \\
\hline \multicolumn{8}{|c|}{ VYARA } \\
\hline 1. & JOL-13-05 X GJO-3 & 282.84 & $3.69(\mathrm{~A})$ & $22.572 * *(\mathrm{G})$ & $25.414 * *(\mathrm{G})$ & $9.846(\mathrm{~A})$ & First Flowering node \\
\hline 2. & AOL-12-144 X GJO-3 & 275.07 & $0.84(\mathrm{~A})$ & $-1.412(\mathrm{G})$ & $25.414 * *(\mathrm{G})$ & $15.266(\mathrm{~A})$ & Fiber content \\
\hline
\end{tabular}

G: (Good) Significant in desired direction, A: (Average) Non significant but in desired direction and P: (Poor) Significant or Non-significant in undesired direction

Table.2 ANOVA for combining ability and estimates of genetic components of variance for pooled over environments

\begin{tabular}{|c|c|c|c|c|c|c|c|c|c|}
\hline Source & & $\begin{array}{c}\text { Days to } 50 \% \\
\text { flowering }\end{array}$ & $\begin{array}{c}\text { First } \\
\text { flowering } \\
\text { node }\end{array}$ & $\begin{array}{l}\text { Inter nodal } \\
\text { length }(\mathrm{cm})\end{array}$ & $\begin{array}{c}\text { Branches per } \\
\text { plant }\end{array}$ & $\begin{array}{c}\text { Fruits per } \\
\text { plant }\end{array}$ & $\begin{array}{l}\text { Plant height } \\
(\mathrm{cm})\end{array}$ & $\begin{array}{l}\text { Days to first } \\
\text { picking }\end{array}$ & $\begin{array}{l}\text { Days to last } \\
\text { picking }\end{array}$ \\
\hline Environments & 2 & $581.309 * *$ & $19.449 * *$ & $108.638^{* *}$ & $43.341 * *$ & $176.411 * *$ & $16255.785^{* *}$ & $592.363 * *$ & $293.111 * *$ \\
\hline Replication & 2 & 0.224 & $1.598 * *$ & 1.507 & $0.626 * *$ & 1.299 & $522.822 * *$ & 0.336 & 0.190 \\
\hline Hybrids & 54 & $30.176^{* *}$ & $0.993 * *$ & $2.772 * *$ & $0.633 * *$ & $74.337 * *$ & $476.781 * *$ & $24.509 * *$ & $20.156 * *$ \\
\hline Females (F) & 10 & $93.568 * *$ & 0.397 & 0.772 & 1.123 & $115.234^{*}$ & $1034.162 * *$ & $70.971 * *$ & 7.573 \\
\hline Males (M) & 4 & 11.441 & 0.353 & 4.056 & 0.330 & $259.091 * *$ & 399.888 & 10.241 & 28.631 \\
\hline Hybrids x Environments & 108 & $26.062 * *$ & $1.021 * *$ & $2.000 * *$ & $0.467 * *$ & $8.544 * *$ & $259.146^{* *}$ & $24.082^{* *}$ & $28.223 * *$ \\
\hline Female x Environment & 20 & 28.154 & $1.626^{*}$ & 1.911 & 0.547 & 3.855 & 374.420 & 22.008 & 26.583 \\
\hline Male x Environment & 8 & 8.875 & 0.518 & 2.183 & 0.330 & 3.755 & 147.416 & 7.892 & 26.868 \\
\hline (F x M) x Environments & 80 & $27.258 * *$ & $0.921 * *$ & $2.004 * *$ & $0.461 * *$ & $10.196 * *$ & $241.500 * *$ & $26.220 * *$ & $28.768 * *$ \\
\hline Pooled Error & 324 & 5.315 & 0.333 & 0.575 & 0.117 & 3.006 & 110.208 & 5.387 & 11.021 \\
\hline
\end{tabular}




\begin{tabular}{|c|c|c|c|c|c|c|c|c|c|}
\hline \multicolumn{10}{|l|}{ Estimates } \\
\hline \multicolumn{2}{|l|}{$\sigma_{f}^{2}$} & $1.961 * *$ & 0.001 & 0.004 & 0.022 & $2.494 *$ & $20.532 * *$ & $1.457 * *$ & 1.457 \\
\hline \multicolumn{2}{|l|}{$\sigma_{m}^{2}$} & 0.062 & 0.000 & 0.035 & 0.002 & $2.587 * *$ & 2.926 & 0.049 & 0.049 \\
\hline \multicolumn{2}{|l|}{$\sigma_{\mathrm{fm}}^{2}$} & $1.210 * *$ & $0.097 * *$ & $0.285^{*}$ & $0.047 * *$ & $4.737 * *$ & $11.5139 * *$ & $0.993 * *$ & $1.270 * *$ \\
\hline \multicolumn{2}{|l|}{$\sigma^{2}$ sca } & $1.210 * *$ & $0.097 * *$ & $0.285^{*}$ & $0.047 * *$ & $4.737 * *$ & $11.5139 * *$ & $0.993 * *$ & $1.270 * *$ \\
\hline \multicolumn{2}{|l|}{$\sigma^{2}$ gca/ $\sigma^{2}$ sca } & 0.517 & 0.010 & 0.091 & 0.191 & 0.540 & 0.425 & 0.492 & 0.077 \\
\hline \multirow[t]{3}{*}{ Contribution (\%) } & $\mathrm{F}$ & 57.420 & 7.410 & 5.156 & 32.840 & 28.710 & 40.168 & 53.624 & 6.958 \\
\hline & M & 2.810 & 2.635 & 10.840 & 3.860 & 25.820 & 6.213 & 3.095 & 10.522 \\
\hline & $\mathrm{F} \times \mathrm{M}$ & 39.770 & 89.955 & 84.004 & 63.300 & 45.480 & 53.620 & 43.280 & 82.520 \\
\hline
\end{tabular}

Table.3 ANOVA for combining ability and estimates of genetic components of variance for pooled over environments

\begin{tabular}{|c|c|c|c|c|c|c|c|c|c|c|}
\hline \multicolumn{2}{|l|}{ Source } & & $\begin{array}{c}\text { Fruit length } \\
\text { (cm) }\end{array}$ & $\begin{array}{l}\text { Fruit diameter } \\
(\mathbf{c m})\end{array}$ & $\begin{array}{l}\text { Stalk length } \\
(\mathrm{cm})\end{array}$ & $\begin{array}{c}\text { Fruit weight } \\
\text { (g) }\end{array}$ & $\begin{array}{c}\text { Seeds per } \\
\text { fruit }\end{array}$ & $\begin{array}{c}100 \text { seed } \\
\text { weight }(\mathrm{g})\end{array}$ & $\begin{array}{l}\text { Fruit yield per } \\
\text { plant }(\mathrm{g})\end{array}$ & $\begin{array}{c}\text { Fiber } \\
\text { content }\end{array}$ \\
\hline \multicolumn{2}{|l|}{ Environments } & 2 & $167.147 * *$ & 0.027 & $0.066^{*}$ & $355.175 * *$ & $338.488 * *$ & $1.344 *$ & $34367.157 * *$ & 0.026 \\
\hline \multicolumn{2}{|l|}{ Hybrids } & 54 & $4.549 * *$ & $0.020 * *$ & $0.031 * *$ & $7.447 * *$ & $76.743 * *$ & $0.542 * *$ & $10863.951 * *$ & $0.472 * *$ \\
\hline \multicolumn{2}{|l|}{ Females (F) } & 10 & 5.347 & 0.023 & 0.015 & 11.572 & 101.956 & 0.507 & 12842.948 & 0.378 \\
\hline \multicolumn{2}{|l|}{ Males (M) } & 4 & 2.444 & 0.027 & 0.010 & 4.455 & 83.398 & 1.149 & $48288.648 * *$ & 0.515 \\
\hline \multicolumn{2}{|l|}{ Females x Males (F x M) } & 40 & $4.560 * *$ & $0.018 * *$ & $0.038 * *$ & $6.715^{* *}$ & $69.774 * *$ & $0.490 * *$ & $6626.732 * *$ & $0.491 * *$ \\
\hline \multicolumn{2}{|l|}{ Hybrids x Environments } & 108 & $3.970 * *$ & $0.024 * *$ & $0.038 * *$ & 1.939 & $32.962 *$ & 0.374 & $1592.269 * *$ & $0.316 * *$ \\
\hline \multicolumn{2}{|l|}{ Female x Environment } & 20 & 5.333 & 0.020 & 0.040 & 1.092 & $66.155^{* *}$ & 0.157 & 1283.639 & 0.212 \\
\hline \multicolumn{2}{|l|}{ Male x Environment } & 8 & 3.536 & $0.061 * *$ & 0.037 & $4.072 *$ & 23.054 & 0.431 & 433.939 & 0.139 \\
\hline \multicolumn{2}{|l|}{ (F x M) x Environments } & 80 & $3.673 * *$ & $0.021 * *$ & $0.038 * *$ & 1.938 & 25.654 & $0.423 *$ & $1785.259 * *$ & $0.360 * *$ \\
\hline \multicolumn{2}{|l|}{ Pooled Error } & 324 & 0.8749 & 0.010 & 0.011 & 2.473 & 24.451 & 0.296 & 623.431 & 0.069 \\
\hline \multicolumn{11}{|l|}{ Estimates } \\
\hline \multicolumn{2}{|l|}{$\sigma_{f}^{2}$} & & 0.099 & 0.000 & 0.000 & 0.202 & 1.722 & 0.005 & 271.545 & 0.007 \\
\hline \multicolumn{2}{|l|}{$\sigma_{m}^{2}$} & & 0.016 & 0.000 & 0.000 & 0.020 & 0.595 & 0.009 & $481.467 * *$ & 0.005 \\
\hline \multicolumn{2}{|l|}{$\sigma^{2} \operatorname{sca}$} & & $0.409 * *$ & $0.001 * *$ & $0.003 * *$ & $0.471 * *$ & $5.036 * *$ & $0.022 * *$ & $667.034 * *$ & $0.047 * *$ \\
\hline \multicolumn{2}{|l|}{$\sigma^{2}$ gca/ $\sigma^{2}$ sca } & & 0.103 & 1.000 & 0.000 & 0.163 & 0.188 & 0.318 & 0.623 & 0.106 \\
\hline \multirow[t]{3}{*}{ Contribution (\%) } & $\mathrm{F}$ & & 21.769 & 21.800 & 8.908 & 28.777 & 24.600 & 17.337 & 21.890 & 14.842 \\
\hline & $\mathrm{M}$ & & 3.979 & 10.232 & 2.256 & 4.432 & 8.050 & 15.706 & 32.920 & 8.082 \\
\hline & $\mathrm{F} \times \mathrm{M}$ & & 74.252 & 67.967 & 88.837 & 66.791 & 67.340 & 66.957 & 45.180 & 77.076 \\
\hline
\end{tabular}


Table.4 Best general combiner and best specific combining crosses along with their per se performance as well as best heterotic crosses for different traits at Navsari

\begin{tabular}{|c|c|c|c|c|c|c|c|c|c|c|c|c|}
\hline \multirow{2}{*}{$\begin{array}{l}\text { Sr. } \\
\text { No. }\end{array}$} & \multirow[t]{2}{*}{ Traits } & \multicolumn{2}{|c|}{ Best performing parents } & \multicolumn{2}{|c|}{ Good general combiners } & \multicolumn{2}{|c|}{ Best cross per se } & \multicolumn{2}{|c|}{$\begin{array}{l}\text { Most heterotic cross over check } \\
\text { "OH-102" }\end{array}$} & \multicolumn{3}{|c|}{ Best specific crosses } \\
\hline & & Parent & Mean & Parent & $g c a$ effect & & & & & Cross & sca effect & Combination \\
\hline 1 & $\begin{array}{l}\text { Days to 50\% } \\
\text { flowering }\end{array}$ & JOL-69-05 & 41.67 & AOL-14-32 & $-2.121 * *$ & $\begin{array}{c}\text { AOL-14-32 x Prabhani } \\
\text { Kranti, AOL-14-32 X } \\
\text { Arka Abhay, , JOL-14- } \\
10 \text { X Parbhani Kranti } \\
\text { and JOL-14-10 X Arka } \\
\text { Anamika }\end{array}$ & 40.33 & $\begin{array}{c}\text { AOL-14-32 X } \\
\text { Parbhani Kranti, } \\
\text { AOL-14-32 X Arka } \\
\text { Abhay, JOL-14-10 X } \\
\text { Parbhani Kranti and } \\
\text { JOL-14-10 X Arka } \\
\text { Anamika }\end{array}$ & $-11.03 *$ & $\begin{array}{l}\text { AOL-12-52 X } \\
\text { GJO-3 }\end{array}$ & $-3.89 * *$ & Poor x Poor \\
\hline 2 & $\begin{array}{l}\text { First flowering } \\
\text { node }\end{array}$ & AOL-12-144 & 3.00 & JOL-69-05 & $-0.354 * *$ & JOL-11-12 X GAO-5 & 3.13 & $\begin{array}{c}\text { JOL-11-12 X GAO- } \\
5\end{array}$ & $-30.88 * *$ & $\begin{array}{l}\text { AOL-12-144 X } \\
\text { GAO-5 }\end{array}$ & $-0.953 * *$ & Poor x Average \\
\hline 3 & $\begin{array}{l}\text { Inter nodal length } \\
\text { (cm) }\end{array}$ & AOL-12-59 & 9.27 & AOL-12-133 & $-0.358 *$ & $\begin{array}{l}\text { AOL-14-32 X Arka } \\
\text { Anamika }\end{array}$ & 7.80 & $\begin{array}{l}\text { AOL-14-32 X Arka } \\
\text { Anamika }\end{array}$ & $-17.02 * *$ & $\begin{array}{l}\text { AOL-14-32 X } \\
\text { Arka Anamika }\end{array}$ & $-1.552 * *$ & Average $x$ Average \\
\hline 4 & $\begin{array}{l}\text { Branches per } \\
\text { plant }\end{array}$ & Arka Abhay & 3.17 & AOL-13-73 & $0.270 * *$ & $\begin{array}{c}\text { AOL-12-144 X Arka } \\
\text { Abhay }\end{array}$ & 3.67 & $\begin{array}{c}\text { AOL-12-144 X Arka } \\
\text { Abhay }\end{array}$ & $34.15 * *$ & $\begin{array}{l}\text { AOL-12-144 X } \\
\text { Arka Abhay }\end{array}$ & $0.868 * *$ & Average $x$ Average \\
\hline 5 & Fruits per plant & JDNOL-11-12 & 19.67 & JOL-14-10 & $2.256 * *$ & $\begin{array}{c}\text { AOL-12-144 X Arka } \\
\text { Abhay }\end{array}$ & 23.53 & $\begin{array}{c}\text { AOL-12-144 X Arka } \\
\text { Abhay }\end{array}$ & 13.50 & $\begin{array}{c}\text { JOL-13-05 X } \\
\text { Parbhani Kranti }\end{array}$ & $6.024 * *$ & Average $x$ Poor \\
\hline 6 & plant height (cm) & Arka Anamika & 105.33 & AOL-12-133 & $14.997 * *$ & AOL-12-52 X GAO-5 & 124.57 & $\begin{array}{l}\text { AOL-12-52 X GAO- } \\
5\end{array}$ & 19.64 & $\begin{array}{l}\text { AOL-12-144 X } \\
\text { Arka Abhay }\end{array}$ & $22.108 * *$ & Average $x$ Poor \\
\hline 7 & $\begin{array}{l}\text { Days to first } \\
\text { picking }\end{array}$ & JOL-69-05 & 47.80 & JOL-14-10 & $-2.006 * *$ & $\begin{array}{l}\text { AOL-14-32 X Parbhani } \\
\text { Kranti }\end{array}$ & 46.30 & $\begin{array}{l}\text { AOL-14-32 X } \\
\text { Parbhani Kranti }\end{array}$ & $-10.27 * *$ & $\begin{array}{l}\text { AOL-12-52 X } \\
\text { GJO-3 }\end{array}$ & $-3.513 * *$ & Poor x Poor \\
\hline 8 & $\begin{array}{l}\text { Days to last } \\
\text { picking }\end{array}$ & $\begin{array}{l}\text { JOL-11-12 } \\
\text { (104.13 days) }\end{array}$ & 104.13 & AOL-14-32 & $2.377 * *$ & $\begin{array}{l}\text { JOL-69-05 X Parbhani } \\
\text { Kranti }\end{array}$ & 107.20 & $\begin{array}{l}\text { JOL-69-05 X } \\
\text { Parbhani Kranti }\end{array}$ & $6.45 *$ & $\begin{array}{l}\text { JOL-69-05 X } \\
\text { Parbhani Kranti }\end{array}$ & $5.400 * *$ & Average $x$ Poor \\
\hline 9 & Fruit length (cm) & JOL-13.05 & 12.89 & JOL-11-12 & $1.243 * *$ & $\begin{array}{l}\text { AOL-14-32 X Arka } \\
\text { Anamika }\end{array}$ & 13.05 & $\begin{array}{l}\text { AOL - 14-32 X Arka } \\
\text { Anamika }\end{array}$ & $11.99 * *$ & $\begin{array}{l}\text { JOL-13-05 X } \\
\text { GJO-3 }\end{array}$ & $2.324 * *$ & Poor x Poor \\
\hline 10 & $\begin{array}{l}\text { Fruit diameter } \\
(\mathbf{c m})\end{array}$ & Arka Abhay & 1.55 & AOL-12-59 & $0.067 * *$ & JOL-69-05 X GAO-5 & 1.64 & $\begin{array}{l}\text { JOL-69-05 X GAO- } \\
5\end{array}$ & 7.66 & $\begin{array}{l}\text { JOL-14-10 X } \\
\text { Arka Abhay }\end{array}$ & $0.154 * *$ & Average $x$ Average \\
\hline 11 & Stalk length (cm) & $\begin{array}{l}\text { Prabahni } \\
\text { Kranti }\end{array}$ & 2.71 & AOL-12-59 & $-0.123 * *$ & $\begin{array}{l}\text { AOL-12-59 X Parbhani } \\
\text { Kranti }\end{array}$ & 2.63 & $\begin{array}{l}\text { AOL-12-59 X } \\
\text { Parbhani Kranti }\end{array}$ & $-14.72 * *$ & $\begin{array}{l}\text { AOL-13-73 X } \\
\text { Arka Anamika }\end{array}$ & $-0.196 * *$ & Average $x$ Average \\
\hline 12 & Fruit weight (g) & JOL-13-05 & 16.02 & AOL-12-133 & $1.000 *$ & $\begin{array}{c}\text { AOL-12-133 X Arka } \\
\text { Abhay }\end{array}$ & 16.50 & $\begin{array}{c}\text { AOL-12-133 X Arka } \\
\text { Abhay }\end{array}$ & 16.77 & $\begin{array}{l}\text { AOL-12-59 X } \\
\text { Arka Anamika }\end{array}$ & $2.322 * *$ & Poor x Average \\
\hline 13 & Seeds per fruit & Arka Anamika & 37.00 & AOL-12-133 & $-3.392 * *$ & AOL-12-59 X GJO-3 & 38.07 & $\begin{array}{l}\text { AOL-12-59 X GJO- } \\
3\end{array}$ & -2.06 & $\begin{array}{c}\text { JDNOL-11-12 X } \\
\text { Arka Anamika }\end{array}$ & -5.360 & Poor x Average \\
\hline 14 & $\begin{array}{l}100 \text { seed weight } \\
\text { (g) }\end{array}$ & AOL-12-52 & 3.80 & AOL-12-52 & $-0.218 * *$ & $\begin{array}{c}\text { AOL-12-133 X Arka } \\
\text { Abhay }\end{array}$ & 3.94 & $\begin{array}{c}\text { AOL-12-133 X Arka } \\
\text { Abhay }\end{array}$ & -2.47 & $\begin{array}{l}\text { JOL-69-05 X } \\
\text { GJO-3 }\end{array}$ & $-0.505 * *$ & Poor x Poor \\
\hline 15 & $\begin{array}{l}\text { Fruit yield per } \\
\text { plant (g) }\end{array}$ & GJO-3 & 265.62 & JOL-14-10 & $34.462 * *$ & $\begin{array}{c}\text { JOL-14-10 X Arka } \\
\text { Abhay }\end{array}$ & 310.96 & $\begin{array}{c}\text { JOL-14-10 X Arka } \\
\text { Abhay }\end{array}$ & 2.23 & $\begin{array}{c}\text { JOL-13-05 X } \\
\text { Parbhani Kranti }\end{array}$ & 63.736** & Average $x$ Poor \\
\hline 16 & Fiber content (\%) & JDNOL-11-12 & 3.90 & Arka Abhay & $-0.112 *$ & $\begin{array}{l}\text { JOL-13-05 X Parbhani } \\
\text { Kranti }\end{array}$ & 3.78 & $\begin{array}{c}\text { JOL-13-05 X } \\
\text { Parbhani Kranti }\end{array}$ & $-25.33 * *$ & $\begin{array}{c}\text { JOL-13-05 X } \\
\text { Parbhani Kranti }\end{array}$ & $-0.846 * *$ & Average $x$ Average \\
\hline
\end{tabular}

G: (Good) Significant in desired direction, A: (Average) Non significant but in desired direction and P: (Poor) Significant or Non-significant in undesired direction 
Table.5 Best general combiner and best specific combining crosses along with their per se performance as well as best heterotic crosses for different traits at Achhalia

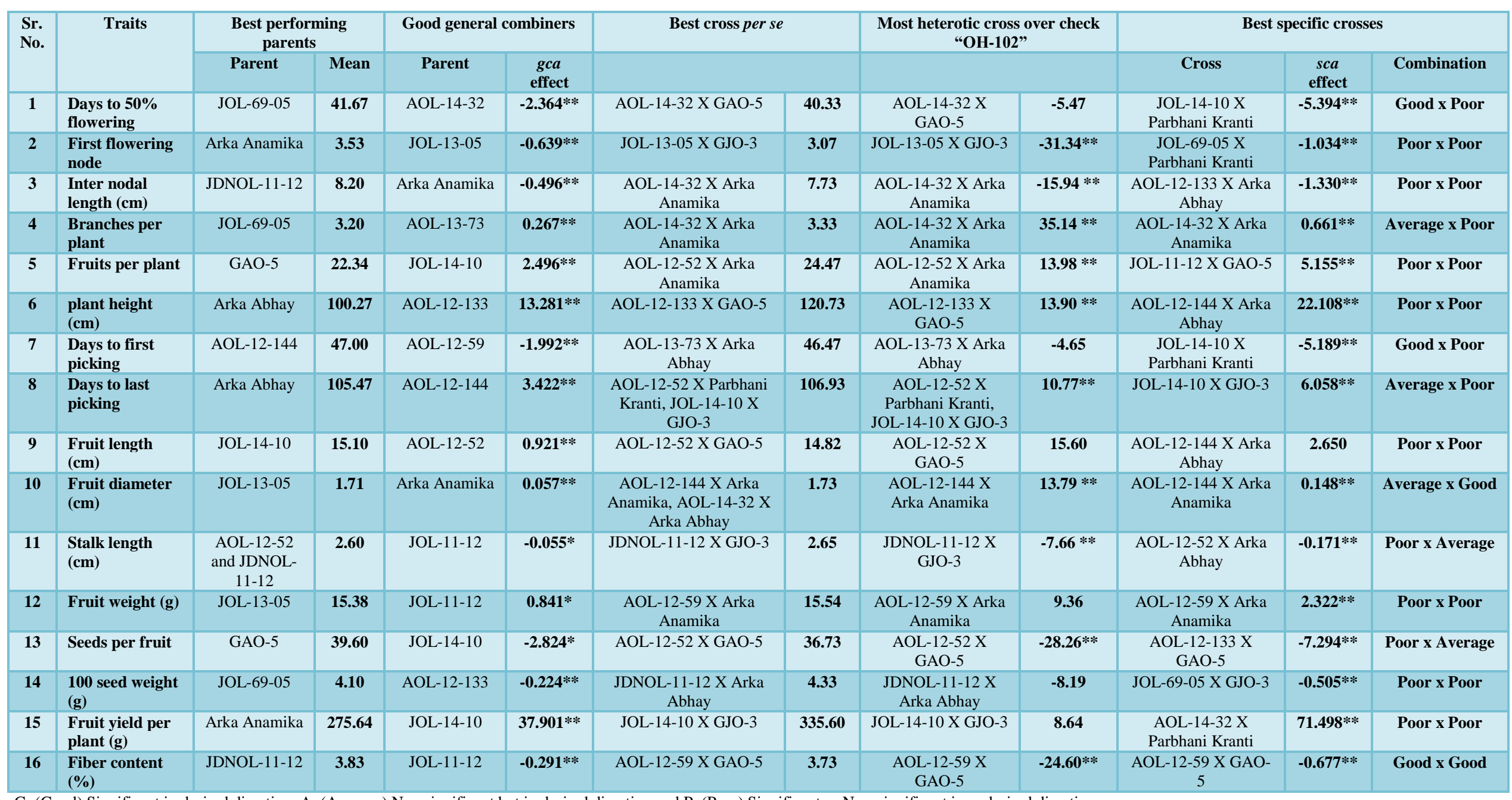


Table.6 Best general combiner and best specific combining crosses along with their per se performance as well as best heterotic crosses for different traits at Vyara

\begin{tabular}{|c|c|c|c|c|c|c|c|c|c|c|c|c|}
\hline \multirow{3}{*}{$\begin{array}{l}7.5 \\
\\
1\end{array}$} & \multirow{3}{*}{\begin{tabular}{|l}
\multicolumn{1}{|c|}{ Traits } \\
$\begin{array}{l}\text { Days to 50\% } \\
\text { flowering }\end{array}$ \\
\end{tabular}} & \multicolumn{2}{|c|}{ Best performing parents } & \multicolumn{2}{|c|}{ Good general combiners } & \multicolumn{2}{|l|}{ Best cross per se } & \multicolumn{2}{|c|}{$\begin{array}{l}\text { Most heterotic cross over check } \\
\text { "OH-102" }\end{array}$} & \multicolumn{3}{|c|}{ Best specific crosses } \\
\hline & & \multirow{2}{*}{$\begin{array}{l}\text { Parent } \\
\text { GAO-5 }\end{array}$} & \multirow{2}{*}{\begin{tabular}{r|} 
Mean \\
43.33
\end{tabular}} & \multirow{2}{*}{$\begin{array}{c}\text { Parent } \\
\text { JOL-14-10 }\end{array}$} & \multirow{2}{*}{$\begin{array}{c}\begin{array}{c}g c a \\
\text { effect }\end{array} \\
-1.655^{* *}\end{array}$} & & & & & Cross & sca effect & Combination \\
\hline & & & & & & $\begin{array}{l}\text { AOL-13-72 X Prabhani } \\
\text { Kranti }\end{array}$ & 43.00 & $\begin{array}{l}\text { AOL-13-72 X Prabhani } \\
\text { Kranti }\end{array}$ & -9.15 & $\begin{array}{l}\text { AOL-12-144 X } \\
\text { GJO-3 }\end{array}$ & $-5.242 * *$ & Poor x Poor \\
\hline 2 & $\begin{array}{l}\text { First flowering } \\
\text { node }\end{array}$ & JDNOL-11-12 & 2.87 & AOL-12-133 & $-0.490 * *$ & $\begin{array}{l}\text { JOL-14-10 X Arka } \\
\text { Abhay }\end{array}$ & 2.73 & JOL-14-10 X Arka Abhay & $-36.93 * *$ & $\begin{array}{c}\text { JOL-14-10 X Arka } \\
\text { Abhay }\end{array}$ & $-1.143 * *$ & Poor x Poor \\
\hline 3 & $\begin{array}{l}\text { Inter nodal } \\
\text { length }(\mathrm{cm})\end{array}$ & GJO-3 & 9.60 & GJO-3 & $-0.522 * *$ & $\begin{array}{c}\text { AOL-12-52 X Arka } \\
\text { Anamika, AOL-12-59 X } \\
\text { GAO-5 }\end{array}$ & 9.07 & $\begin{array}{c}\text { AOL-12-52 X Arka } \\
\text { Anamika, AOL-12-59 X } \\
\text { GAO-5 }\end{array}$ & -4.23 & $\begin{array}{l}\text { AOL-12-59 X GAO- } \\
5\end{array}$ & $-1.490 * *$ & Average x Poor \\
\hline 4 & $\begin{array}{l}\text { Branches per } \\
\text { plant }\end{array}$ & $\begin{array}{l}\text { AOL-13-73, AOL-12- } \\
\text { 144, AOL-12-133, JOL- } \\
\text { 11-12, JOL-13-05 }\end{array}$ & 2.00 & AOL-14-32 & 0.301 ** & $\begin{array}{c}\text { AOL-12-133 X GAO-5, } \\
\text { JOL-69-05 X Parbhani } \\
\text { Kranti }\end{array}$ & 2.60 & $\begin{array}{c}\text { AOL-12-133 X GAO-5, } \\
\text { JOL-69-05 X Parbhani } \\
\text { Kranti }\end{array}$ & $39.29 * *$ & $\begin{array}{l}\text { AOL-12-133 X } \\
\text { GAO-5 }\end{array}$ & 0.708 ** & Poor x Average \\
\hline 5 & Fruits per plant & GAO-5 & 22.34 & JOL-14-10 & 1.990 ** & JDNOL-11-12 X GJO-3 & 23.73 & JDNOL-11-12 X GJO-3 & 4.71 & $\begin{array}{l}\text { AOL-14-32 X Arka } \\
\text { Anamika }\end{array}$ & $5.348 * *$ & Poor x Good \\
\hline 6 & $\begin{array}{l}\text { plant height } \\
\text { (cm) }\end{array}$ & GJO-3 & 100.93 & AOL-12-52 & $9.121 * *$ & AOL-12-144 X GJO-3 & 102 & AOL-12-144 X GJO-3 & 10.60 & $\begin{array}{l}\text { AOL-14-32 X } \\
\text { Parbhani Kranti }\end{array}$ & $20.532 * *$ & Poor x Good \\
\hline 7 & $\begin{array}{l}\text { Days to first } \\
\text { picking }\end{array}$ & Parbhani Kranti & 49.73 & AOL-12-59 & -1.568 & $\begin{array}{l}\text { AOL-13-73 X Parbhani } \\
\text { Kranti }\end{array}$ & 49.60 & $\begin{array}{c}\text { AOL-13-73 X Parbhani } \\
\text { Kranti }\end{array}$ & -7.69 & $\begin{array}{l}\text { AOL-12-144 X } \\
\text { GJO-3 }\end{array}$ & $-4.815^{* *}$ & Poor x Poor \\
\hline 8 & $\begin{array}{l}\text { Days to last } \\
\text { picking }\end{array}$ & Arka Abhay & 104.73 & GAO-5 & 1.175 & JDNOL-11-12 X GJO-3 & 106.13 & JDNOL-11-12 X GJO-3 & 4.46 & $\begin{array}{c}\text { JOL-69-05 X Arka } \\
\text { Abhay }\end{array}$ & $6.627^{* *}$ & Poor x Poor \\
\hline 9 & $\begin{array}{l}\text { Fruit length } \\
\text { (cm) }\end{array}$ & JOL-14-10 & 10.74 & AOL-14-32 & $0.896 * *$ & $\begin{array}{l}\text { AOL-14-32 X Parbhani } \\
\text { Kranti }\end{array}$ & 12.67 & $\begin{array}{l}\text { AOL-14-32 X Parbhani } \\
\text { Kranti }\end{array}$ & 17.56 ** & $\begin{array}{l}\text { AOL-12-144 X Arka } \\
\text { Abhay }\end{array}$ & 2.650 ** & Poor x Poor \\
\hline 10 & $\begin{array}{l}\text { Fruit diameter } \\
\text { (cm) }\end{array}$ & AOL-14-32 & 1.58 & JOL-13-05 & $0.088 * *$ & $\begin{array}{l}\text { JOL-14-10 X Arka } \\
\text { Abhay }\end{array}$ & 1.72 & JOL-14-10 X Arka Abhay & 10.47 & $\begin{array}{c}\text { JOL-14-10 X Arka } \\
\text { Abhay }\end{array}$ & $0.156 *$ & Average x Poor \\
\hline 11 & $\begin{array}{l}\text { Stalk length } \\
\text { (cm) }\end{array}$ & AOL-12-59 & 2.60 & JOL-69-05 & $-0.055 * *$ & $\begin{array}{l}\text { JOL-14-10 X Arka } \\
\text { Abhay }\end{array}$ & 2.65 & JOL-14-10 X Arka Abhay & $-7.78 * * *$ & $\begin{array}{c}\text { JOL-14-10 X Arka } \\
\text { Abhay }\end{array}$ & $-0.179 * *$ & Average $\mathbf{x}$ Poor \\
\hline 12 & Fruit weight (g) & JOL-13-05 & 13.47 & AOL-14-32 & $1.140^{* *}$ & AOL-14-32 X GAO-5 & 13.84 & AOL-14-32 X GAO-5 & 17.09 & $\begin{array}{l}\text { AOL-12-59 X Arka } \\
\text { Anamika }\end{array}$ & 2.083* & Poor x Poor \\
\hline 13 & Seeds per fruit & Arka Anamika & 37.00 & AOL-12-133 & $-2.973 * *$ & AOL-12-59 X GJO-3 & 38.07 & AOL-12-59 X GJO-3 & -5.31 & $\begin{array}{l}\text { JOL-11-12 X GAO- } \\
5\end{array}$ & $-7.932 * *$ & Poor x Poor \\
\hline 14 & $\begin{array}{l}100 \text { seed weight } \\
\text { (g) }\end{array}$ & GAO-5 & 3.79 & $\begin{array}{l}\text { Parbhani } \\
\text { Kranti }\end{array}$ & -0.135 & JOL-11-12 X GJO-3 & 3.84 & JOL-11-12 X GJO-3 & -5.03 & JOL-11-12 X GJO-3 & -0.715 & Average $x$ Average \\
\hline 15 & $\begin{array}{l}\text { Fruit yield per } \\
\text { plant }(\mathrm{g})\end{array}$ & AOL-12-52 & 210.75 & GJO-3 & $25.414 * *$ & JOL-13-05 X GJO-3 & 282.84 & JOL-13-05 X GJO-3 & 3.69 & $\begin{array}{l}\text { AOL-14-32 X } \\
\text { Parbhani Kranti }\end{array}$ & $62.641 * *$ & Average x Poor \\
\hline 16 & $\begin{array}{l}\text { Fiber content } \\
(\%)\end{array}$ & Prabhani Kranti & 3.93 & AOL-13-73 & $-0.214 * *$ & $\begin{array}{l}\text { JOL-11-12 X Parbhani } \\
\text { Kranti }\end{array}$ & 3.73 & $\begin{array}{l}\text { JOL-11-12 X Parbhani } \\
\text { Kranti }\end{array}$ & $-18.91 * *$ & $\begin{array}{c}\text { JOL-11-12 X } \\
\text { Parbhani Kranti }\end{array}$ & $-0.788 * *$ & Average $x$ Average \\
\hline
\end{tabular}

G: (Good) Significant in desired direction, A: (Average) Non significant but in desired direction and P: (Poor) Significant or Non-significant in undesired direction 
A summarized account of best $\mathrm{F}_{1}$ per se, most heterotic crosses and best specific combinations in Table 4, 5 and 6 at Navsari, Achhalia and Vyara, respectively indicated that at Navsari hybrids viz., AOL-14-32 X Arka Anamika (average $\mathrm{x}$ average) for internodal length, AOL-12-144 X Arka Abhay (average $\mathrm{x}$ average) for branches per plant, JOL-69-05 X Parbhani Kranti (Average $\mathrm{x}$ Poor) for days to last picking and JOL-1305 X Parbhani Kranti (average x average) for fiber content recorded as higher sca effects with higher heterosis and per se performance. At Achhalia hybrids, AOL-14-32 X Arka Anamika (average $\mathrm{x}$ poor) for branches per plant, JOL-14-10 X GJO-3 (Average x Poor) for days to last picking, AOL-12-144 X Arka Anamika (average $\mathrm{x}$ good) for fruit diameter, AOL-12-59 X Arka Anamika (poor x poor) for fruit weight and AOL-12-59 X GAO-5 (good $\mathrm{x}$ good) for fiber content exhibited higher sca effects with highest heterosis and per se performance. At Vyara hybrids, JOL14-10 X Arka Abhay (poor x poor) for first flowering node and (average $\mathrm{x}$ poor) for fruit diameter and stalk length, AOL-12-59 X GAO-5 (average $x$ poor) for internodal length, AOL-12-133 X GAO-5 (poor $x$ average) for branches per plant, JOL-11-12 X GJO-3 (average $\mathrm{x}$ average) for 100 seed weight and JOL-11-12 X Parbhani Kranti (average X average) for fiber content exhibited higher sca effects with higher heterosis and per se performance. Hybrid JOL-13-05 X Parbhani Kranti (average $\mathrm{x}$ poor) had significant desirable sca effect for fruit yield, fruits per plant and fiber content followed by hybrid AOL-14-32 X Parbhani Kranti exhibited poor $x$ poor combination at Navsari. Hybrid AOL14-32 X Parbhani Kranti (poor $x$ poor) at Achhalia and in pooled analysis and average $\mathrm{x}$ poor at Vyara was reported highest sca effects for fruit yield, fruits per plant and also exhibited good or average sca effects for inter nodal length, plant height, branches per plant, fruit length, fruit weight, seeds per fruit and
100 seed weight. In general, hybrid AOL-1432 X Parbhani Kranti reported high sca effects in individual as well as pooled over environment for fruit yield and also exhibited good or average sca effects for yield contributing traits.

Appraisal of data (Table 4, 5 and 6) at Navsari, Achhalia and Vyara, respectively revealed that the best performing parents may not be a best general combiner. Further, the best general combiner or best parent per se may not always produce best specific combinations for all the characters. It is further more desirable to select crosses based on per se performance rather than magnitude of sca effects; it has been earlier reported by Jethava (2014), More (2015) and Patel (2015). The hybrids showing low sca effects may exhibit high per se performance. Similar results have been reported by Singh et al., (2006). Hybrid AOL-14-32 X Parbhani Kranti in individual as well as pooled over environment manifested high sca effects for fruit yield but the parents were poor/average general combiners. This observation corroborate with the observations of Kumar and Pathania, (2011), Singh et al., (2011) and Verma et al., (2016) reported in okra that the superior hybrids need not necessarily have parents showing high gca effects.

The hybrids exhibiting high per se performance for fruit yield per plant may results from good $\mathrm{x}$ poor combining parents at Navsari or good $\mathrm{x}$ good general combining parents at Achhalia and Vyara. The good general combining parents when crossed do not always produce high sca effects. Similarly poor general combining parents did not always produce low sca effects. Similar results have been reported by Pachiyappan et al., (2012), More et al., (2017) and Kayande et al., (2018). Marked negative or non significant sca effects in crosses between good $\mathrm{x}$ good and good $\mathrm{x}$ average combiners 
could be attributed to the lack of coadaptation between favorable alleles of the parents involved. Whereas marked positive $s c a$ effects in crosses between poor $\mathrm{x}$ poor, poor $\mathrm{x}$ average or average $\mathrm{x}$ average general combiners could be ascribed to better complementation between favorable alleles of the parents involved Patel and Mehta (1985).

Appraisal of data (Table 4, 5 and 6) revealed that for most of the traits, hybrids exhibiting higher sca effects for fruit yield and yield contributing traits involved poor $\mathrm{x}$ poor, average $\mathrm{x}$ poor, good $\mathrm{x}$ poor and average $\mathrm{x}$ average combiner parents, indicating the presence of both additive and non-additive gene effects for controlling fruit yield and its contributing traits. These results are in agreement with Sharma and Singh (2012), Lyngdoh et al., (2017) and Annapurna and Singh (2018). Some parents with positive and significant general combining ability produced hybrids with negative and significant specific combining ability indicating the role of complementary gene action (Basak and Dana, 1971). The hybrids showed good sca effetcs with involved poor $\mathrm{x}$ poor combining parents indicating overdominance and epistatic interactions. This may be due to genetic diversity in the form of heterozygous loci as reported by Pathak and Dangaria (1987) in castor. A comparison of the hybrids selected on the basis of their sca effects with their mean performance at various location revealed some important features viz., (1) the relative ranking of the various hybrids on the basis of $s c a$ effects was different at different location, (2) the ranking on the basis of sca effects was not always reflected by the ranking based on per se performance (Table 4, 5 and 6) and (3) hybrid, JOL-14-10 X Arka Abhay, JOL-14-10 X GJO-3 and JOL-13-05X GJO-3 at Navsari, Achhalia and Vyara, Respectively showing high mean performance had not always shown high sca effects. There was no consistent association between per se performance of the hybrids and their sca effects (Vasline and Ganesan 1995). Even with the same amount of heterotic effects, the sca effects may be lower where the mean performance of the parent is higher. This suggests that estimates of sca effects may not always lead to a correct choice of hybrid combination. These estimates may also be biased because of non-fulfillment of any of the assumption involved in the models. Hence, the choice of best hybrid combinations on the basis of per se performance could be more realistic and useful. Almost identical results have been reported by Patel and Mehta (1989), Vasline and Ganesan (1995), Pal and Sabesan (2009), Lyngdoh et al., (2017) and Kayande et al., (2018).

In conclusion the extent of possible improvement in yield is usually through screening and selecting out best adapted genotypes from the source population and utilizing them directly or through hybridization to generate high-yielding variety or hybrid. On the basis of the results obtained in the present study, it is apparent that the following points should be kept in mind before undertaking okra breeding programme. On the basis of per se performances, selection of parental lines are important and may be used in future breeding programme. Non-significant and desirable heterosis over standard check for fruit yield and its component traits suggested that there is no scope of exploiting heterosis commercially, but possibility of isolating desirable segregants among these hybrid combinations. Although the relative amount of gca and sca effects play a vital role in planning the most appropriate breeding programme, this objective could be fulfilled by the analysis of variance for combining ability, itself. The estimates of gca effects revealed that the parental lines showing high gca effects for fruit yield per plant used for 
further breeding programme. It is clear from above discussion that the high degree of non additive gene action for all the component traits observed in the present study indicated that improvement of yield and yield component traits go for bi-parental mating, recurrent selection or diallel selective mating (Jensen, 1970) than conventional pedigree or backcross breeding techniques, which would leave the unfixable components of genetic variances unexploited for yield and its components.

\section{Acknowledgement}

The authors acknowledge the support given by NAU and Deprt. of Genetics and Plant Breeding, NMCA, Navsari, Gujarat and ICAR, New Delhi for providing a Ph.D. SRF scholarship. We are also grateful to the group of vegetable scientist of Deprt. of Vegetable Science, NAU, Navsari, Gujarat, India.

\section{References}

Annapurna and Singh, S. P. (2018). Analysis of combining ability status and nature of gene action among hybrids for yield and quality traits in okra [Abelmoschus esculentus (L.) Moench]. Int. J. Pure App. Biosci,. 6 (2): 1547-1553.

Balakrishnan, D. and Sreenivasan, E. (2013). Genetic analysis of fruit and shoot borer (Earias vittella Fab.) resistance in okra (Abelmoschus spp.). Pest Management in Horticultural Ecosystems, 19 (1): 17-22.

Basak S. L. and Dana S (1971). Gene effects and heterosis in jute. Indian $\mathrm{J}$ Genet $\mathrm{Pl}$ Br., 2: 480-485.

Bhatt, J. P., Kathiria, K. B., Christian, S. S. and Acharya, R. R. (2015). Combining ability studies in okra (Abelmoschus esculentus (L.) Moench) for yield and its component characters. Elec. J. Plant Bree., 6(2): 479-485.
Charrier, A. (1984). Genetic resources of the genus Abelmoschus Med. (Okra). IBPGR, Italy, pp. 61.

Das, S., Chattopadhyay, A., Dutta, S., Chattopadhyay, S. and Hazra, P. (2013). Breeding okra for higher productivity and yellow vein mosaic tolerance. Veg. Sci., 19: 58 -77.

Friedt, W., Snowdon, R., Ordon, F. and Ahlemeyer, J. (2007). plant breeding: assessment of genetic diversity in crop plants and its exploitation in breeding. Progress in Botany, 68: 151-178.

Gardner, C.O. and Eberhart, S. S. (1966). Analysis and interpretation of variety cross diallel and related population. Biometrics. 22:439-452.

Gavint, K. N., Vadodariya, K. V. and Bilwal, B. B. (2018). To study the nature and magnitude of heterosis for fruit yield and yield attributes in okra [Abelmoschus esculentus (L.) Moench]. J. Pharmaco. and Phytochem., 7(1): 2583-2587.

Hosamani, R. M., Ajjapalavara, P. S., Patil, Basavarajeshwari C., Smitha, R. P. and Ukkand, K. C. (2008). Heterosis for yield and yield components in okra. Karnataka J. Agric. Sci., 21(3): 473475.

Jethava, B. A. (2014). Heterosis and combining ability in okra (Abelmoschus esculentus (L.) Moench). M.Sc. Thesis, Navsari Agricultural University, Navsari.

Katagi, A., Tirakannanvar, S. and Jagadeesha, R. C. (2015). Combining ability through diallel analysis in okra (Abelmoschus esculentus (L.) Moench). Green Farming Int. J., 6(1): $26-29$.

Kayande, N.V., Kumbhalkar, H. B. and Shinde, S. (2018). Selection of parents based on combining ability studies in okra (Abelmoschus esculentus L. Moench). Int. J. Curr. Microbiol. App. 
Sci., 6: 1935-1940.

Kempthrone, O. (1957). An "Introduction to Genetics Statistics". John Willey and Sons, New York, pp: 453-471.

Kerure, P. and Pitchaimuthu, M. (2018). Heterosis Studies in Okra (Abelmoschus esculentus L. Moench). Int. J. Curr. Microbiol. App. Sci., 7(09): 1851-1862.

Kumar, S. and Pathania, N. P. (2007). Heterosis and combining ability studies for shoot and fruit borer infestation (Earias spp.) in okra (Abelmoschus esculentus (L.) Meonch), The Asian J. Hort., 2(1): 126-130.

Lyngdoh, R., Mulge, R. and Shadap, A. (2013). Heterosis and combining ability studies in near homozygous lines of okra (Abelmoschus esculentus (L.) Moench) for growth parameters. The Bioscan, 8(4): 1275 -1279.

Makdoomi, M. I., Wani, K. P., Dar, Z. A., Hussain, K., Nabi, A., Mushtaq, F. and Mufti, S., (2018). Heterosis studies in okra (Abelmoschus esculentus L. Moench). Int. J. Curr. Microbiol. App. Sc., 7(02): 3297-3304.

Mathar, K. and Jinks, J. L. (1982). Biometrical Genetics, 3rd ed. London: Chapman and Hall Ltd.

Medagam, T. R., Kadiyala, H., Mutyala, G., and Hameedunnisa B. (2012). Heterosis for yield and yield components in okra. Chilean J. Agric. Res., 72(3): 316-325.

Medagam, T. R., Kadiyala, H., Mutyala, G., and Hameedunnisa Begum (2013). Exploitation of heterosis in okra [Abelmoschus esculentus (L.) Moench]. Inter. J. Agric. and Food Res., 2(4): 25-40.

More, S. J., Chaudhari, K. N., Patel, A. I. and Patel, D. (2015). Combining ability analysis for fruit yield and yield attributing traits in okra (Abelmoschus esculentus L. Moench) Trends in Biosci., 8(14): 3630-3637.

More, S. J., Chaudhari, K. N., Vaidya, G. B. and Chawla, S. L. (2017). Multienvironment analyses of genetic components and combining abilities in relation to heterosis in okra [Abelmoschus esculentus (L.) Moench]. Int. J. Curr. Microbiol. App. Sci., 6(12): 2835-2842.

More, S. J., K. Chaudhari, N., Bhanderi, D. R., Saravaiya, S. N. and Chawla, S. L. (2015). Heterosis Study in Okra (Abelmoschus esculentus L. Moench). Trends in Bio., 8(12): 3252-3255.

Oyetunde, O. A. and Ariyo, O.J. (2014). Genetics of seed yield and related traits in biparental crosses of okra, [Abelmoschus esculentus (L.) Moench]. Nigerian J. of Gen., 28(2): 8-14.

Pachiyappan, R., Saravanan, K. and Kumar, R. (2012). Combining ability analysis in eggplant (Solanum melongena L.). Golden Research Thoughts, 2(2): 1-6.

Pal, A. K. and Sabesan, T. (2009). Combining ability through diallel analysis in okra [Abelmoschus esculentus (L.) Moench]. Electro. J. Pl. Breed., 1: 84 88.

Patel, B. H. (2015). Genetic analysis of yield and its quality parameters in okra (Abelmoschus esculentus (L.) Moench), M.Sc. Thesis, Navsari Agriculture university, Navsari.

Patel, U.G. and Mehta, N.P. (1985). Studies on heterosis, combining ability and stability of performance in cotton $(G$. herbaceum L.). Indian J.Genet. 37: 4548.

Pathak, H. C., and Dangaria, C. J. 1987. Combining ability for yield and its components in castor. Indian J. Agric. Sci., 57:13-16.

Patil, S. S. (2013). Genetic analysis for yield and yield contributing traits in okra 
[Abelmoschus esculentus (L.) Moench] over environments. Ph.D. Thesis, Navsari Agricultural University, Navsari.

Poshiya, V. K. and Shukla, P. T. (1986). Heterosis studies in okra [Abelmoschus esculentus (L.) Moench], GAU,. Res. J., 11 (2): 21-25.

Satish, K., Bhatt, K., Suresh, K. and Prajapati, D. B. and Agalodiya, A.V. (2017). Heterosis study in okra (Abelmoschus esculentus L. Moench). Multilogic in Scie., 7(24): 85-89.

Sharma, J. P. and Singh A. K. (2012). Line x Tester analysis for combining ability in okra (Abelmoschus esculentus (L.) Moench). Veg. Sci., 54(1/2): 56-59

Singh, D. (1973). Diallel cross analysis for combining ability over different environments-II. Indian J. Gen. and Plant Bre., 33(3): 469-481.

Singh, S. P. (2011). Combining ability analysis for yield and yield contributing characters in okra. Veg. Sci., 38(2): 212-214.

Solankey, S. S., Singh, A. K. and Singh, R. K. (2013). Genetic expression of heterosis for yield and quality traits during different growing seasons in okra (Abelmoschus esculentus (L.) Moench). Indian J. Agric. Sci., 83(8): 815-819.

Tiwari, J. N., Kumar, Sanjeev, Ahlawat, T. R., Kumar, Akhilesh and Patel, Nishtha (2015). Heterosis for yield and its components in okra [Abelmoschus esculentus (L.) Moench]. Asian J. Hort., 10(2): 201-206.

Vasline, Y. A. and Ganesan, J. (1995). Heterosis and combining ability for certain characters in bhindi, Crop Improvement, 23 (1): 113-114.

Verma, A. and Sood, S. (2015). Genetic expression of heterosis for fruit yield and yield components in intraspecific hybrids of okra [Abelmoschus esculentus (L.) Moench]. SABRAO J. of Bre. and Gen., 47 (3) 221-230.

Verma, A., Sood, S. and Singh Y. (2016). Combining ability studies for yield and contributing traits in okra (Abelmoschus esculentus L. Moench). J. Appl. \& Nat. Sci. 8 (3): 1594-1598.

Vijayaraghavan, C. and Warrier, V. A. (1946). Evaluation of high yielding hybrids in bhendi (Hibischus esculentus). Proceedings of 33rd Indian Science Congress, 33 (33).

Wammanda, D. T., Kadams, A. M. and Jonah, P. M. (2010). Combining ability analysis and heterosis in a diallel cross of okra (Abelmoschus esculentus (L.) Moench). African J. Agric. Res., 5(16): 2108-2115.

Wynne, J. C., Emary, D. A., Rice, P. H. (1970). Combining ability estimation in F1 Arachic hypogea hybrid. Crop Sci., 10: 713-715.

\section{How to cite this article:}

Vekariya, R. D., A. I. Patel, K. G. Modha, C. V. Kapadiya, S. C. Mali and Patel, A. A. 2020. Estimation of Heterosis, Gene Action and Combining Ability over Environments for Improvement of Fruit Yield and its Related Traits in Okra [Abelmoschus esculentus (L.) Moench]. Int.J.Curr.Microbiol.App.Sci. 9(09): 866-881. doi: https://doi.org/10.20546/ijcmas.2020.909.109 